Buletin Ilmiah Math. Stat. dan Terapannya (Bimaster)

Volume 08, No. 4 (2019), hal 721 - 728.

\title{
PEMODELAN AUTOREGRESSIVE FRACTIONALLY INTEGRATED MOVING AVERAGE (ARFIMA) DALAM MEMPREDIKSI HARGA CRUDE PALM OIL (CPO)
}

\author{
Ika Ayu Krismawanti, Shantika Martha, Naomi Nessyana Debataraja
}

\begin{abstract}
INTISARI
Kelapa sawit merupakan salah satu komoditas perkebunan yang dapat berpengaruh terhadap perekonomian Indonesia. Salah satu hasil olahan tanaman kelapa sawit yaitu minyak kelapa sawit mentah (CPO). CPO memiliki peran strategis dalam perekonomian negara khususnya dalam bidang ekspor ke berbagai negara terutama negara India. Harga CPO yang cenderung mengalami peningkatan dan penurunan akan berpengaruh terhadap penghasilan negara dan masyarakat khususnya petani kelapa sawit. Peningkatan dan penurunan harga CPO yang tidak menentu memerlukan peramalan untuk mengetahui harga CPO dimasa yang akan datang. Peramalan merupakan kegiatan dalam memperkirakan kejadian dimasa depan dengan pengambilan data-data dimasa lalu. Dalam analisis runtun waktu terdapat data yang memiliki ciri proses jangka pendek dan data yang memiliki ciri proses jangka panjang. Model yang dapat menangani kedua jenis data ini adalah model autoregressive fractionally integrated moving average (ARFIMA). Model ARFIMA merupakan pengembangan dari model ARIMA, dengan differencing bernilai pecahan. Penelitian ini bertujuan untuk menentukan model ARFIMA pada data harga CPO. Data yang digunakan dalam penelitian ini merupakan data harga CPO dari periode 1 Januari 2012 sampai 10 Maret 2019. Berdasarkan analisis dapat disimpulkan bahwa model ARFIMA terbaik yang didapat adalah ARFIMA (1; 0,17; 0) dengan nilai AIC sebesar 7,999 dan nilai MAPE sebesar 1,37\%.
\end{abstract}

Kata Kunci: $C P O$, peramalan, ARFIMA

\section{PENDAHULUAN}

Indonesia merupakan negara agraris yang didukung oleh sektor pertanian. Salah satu sektor pertanian adalah perkebunan yang saat ini memiliki peranan yang besar dalam pertumbuhan ekonomi. Ditinjau dari segi peningkatan produksinya perkembangan usaha perkebunan telah menunjukan kemajuan yang sangat pesat, seperti komoditas sawit. Pemerintah melalui Kementrian Pertanian periode 2010-2014 menetapkan kelapa sawit merupakan komoditas unggulan utama Indonesia [1]. Salah satu hasil olahan kelapa sawit yaitu minyak kelapa sawit mentah atau yang dikenal dengan crude palm oil (CPO).

CPO merupakan produk perkebunan yang menjadi komoditas ekspor unggulan Indonesia, karena tingkat produksinya paling tinggi di dunia. Hal ini yang menyebabkan $\mathrm{CPO}$ mempunyai peran strategis dalam perekonomian nasional. Minyak kelapa sawit merupakan 10 komoditas utama ekspor non-migas yang masuk dalam komoditas industri pengolahan. Pada tahun 2017, lima besar negara pengimpor CPO Indonesia adalah India, Belanda, Singapura, Italia, dan Spanyol. India merupakan negara tujuan ekspor CPO terbesar dengan volume ekspor ke India mencapai 4,63 juta ton atau 65,40\% dari total volume ekspor CPO Indonesia dengan nilai US\$ 3,068 juta [2]. Saat ini CPO memegang peranan penting dalam industri perdagangan ekspor Indonesia. Oleh karena itu, mengetahui bagaimana pergerakan harga CPO sangat penting demi kestabilan ekonomi Indonesia sehingga diperlukan peramalan untuk memprediksi harga CPO yang akan datang.

Peramalan merupakan upaya untuk memperkirakan apa yang terjadi pada masa yang akan datang berdasarkan pada nilai masa lalu dari suatu variabel [3]. Dalam analisis runtun waktu dapat ditemui data runtun waktu yang tidak stasioner dan plot autocorrelation function (ACF) yang turun secara lambat atau hiperbolik. Data seperti ini menunjukkan pola memori jangka panjang (long memory). Model runtun waktu yang cocok dengan data long memory yaitu autoregressive fractionally integrated moving average (ARFIMA) [4]. Model ARFIMA dapat mengatasi kelemahan pada model autoregressive integrated moving average (ARIMA) yaitu model ARIMA hanya dapat menjelaskan runtun waktu 
jangka pendek, sedangkan model ARFIMA mampu menjelaskan runtun waktu jangka pendek maupun jangka panjang [5]. Penelitian ini bertujuan untuk melakukan pemodelan harga CPO dengan menggunakan pendekatan deret berkala memori jangka panjang ARFIMA. Langkah pertama dalam penelitian ini adalah uji stasioneritas data melalui plot runtun waktu. Apabila data tidak stasioner dalam variansi, maka dilakukan transformasi Box-Cox untuk menstasionerkan data. Langkah kedua membuat plot autocorrelation function (ACF) dan partial autocorrelation function (PACF). Plot ACF digunakan untuk mengetahui adanya ketergantungan jangka panjang. Kemudian melakukan perhitungan hurst exponent dengan metode rescaled range statistics $(\mathrm{R} / \mathrm{S})$ untuk memperkuat apakah data menunjukkan ketergantungan jangka panjang. Langkah ketiga identifikasi model ARFIMA melalui plot ACF dan PACF. Langkah keempat mengestimasi parameter model ARFIMA dan memilih model yang signifikan. Setelah itu melakukan pemeriksaan model dengan uji Ljung-Box. Selanjutnya menentukan model terbaik berdasarkan nilai akaike's information criterion (AIC) terkecil. Langkah terakhir pada penelitian ini yaitu menentukan hasil peramalan dan nilai mean absolute percentage error (MAPE) sebagai kriteria pengukuran kemampuan peramalan.

\section{ANALISIS RUNTUN WAKTU}

Runtun waktu merupakan serangkaian observasi terhadap suatu variabel yang diambil secara beruntun berdasarkan interval waktu yang tetap. Adapun waktu yang digunakan dapat berupa mingguan, bulanan, tahunan dan sebagainya [3]. Kumpulan pengamatan-pengamatan dalam runtun waktu dinyatakan sebagai variabel yang sering dinotasikan sebagai $Z$. Data-data tersebut diamati pada waktu $t$, yaitu $t_{1}, t_{2}, \ldots, t_{n}$ dan variabel tersebut ditulis dalam notasi $Z_{t_{1}}, Z_{t_{2}}, \ldots, Z_{t_{n}}[6]$. Peramalan runtun waktu menggunakan data di masa lampau untuk meramalkan data di masa mendatang. Model runtun waktu yang umum digunakan adalah ARIMA. Model $\operatorname{ARIMA}(p, d, q)$ dengan $p$ menunjukkan ordo pada model autoregressive (AR), $d$ menunjukkan banyaknya proses differencing (pembedaan), dan $q$ menunjukkan ordo pada model moving average (MA) [6].

Data runtun waktu dikatakan stasioner jika data tersebut berfluktuasi disekitar nilai rata-rata dan variansi yang relatif konstan sepanjang periode waktu. Kestasioneran dalam data runtun waktu dapat dilihat dengan menggunakan plot runtun waktu. Data runtun waktu yang tidak stasioner dalam rata-rata pada umumnya dapat diatasi dengan proses differencing. Jika $Z_{1}, Z_{2}, \ldots, Z_{t}$ adalah suatu data runtun waktu maka operator Backshift didefinisikan sebagai berikut:

$$
B^{d}\left(Z_{t}\right)=Z_{t-d}
$$

dimana notasi $B$ adalah backshift. Pada Persamaan (1) $B$ mempunyai pengaruh menggeser data sebanyak $d$ periode ke belakang [6].

Dalam pemodelan runtun waktu sering juga ditemukan data dengan kondisi tidak stasioner dalam variansi. Untuk menstasionerkan data yang tidak stasioner dalam variansi dapat dilakukan dengan transformasi data. Salah satu transformasi yang dapat digunakan adalah transformasi Box-Cox. Transformasi Box-Cox adalah transformasi pangkat pada respon dengan bentuk transformasi sebagai berikut [7]:

$$
T\left[Z_{t}\right]=Z_{t}^{(\lambda)}=\left\{\begin{array}{l}
\frac{Z_{t}^{(\lambda)}-1}{\lambda}, \lambda \neq 0 \\
\ln Z_{t}, \lambda=0
\end{array}\right.
$$

dimana $\lambda$ merupakan parameter transformasi.

\section{MODEL AUTOREGRESSIVE INTEGRATED MOVING AVERAGE (ARIMA)}

Model autoregressive integrated moving average dapat diterapkan untuk data runtun waktu yang bersifat tidak stasioner. Seringkali data runtun waktu yang tidak stasioner pada ordo pertama akan 
menjadi stasioner jika dilakukan differencing satu kali. Demikian apabila menggunakan data runtun waktu yang sudah dilakukan differencing sebanyak $d$ kali agar stasioner dan diterapkan pada model $\operatorname{ARMA}(p, q)$ maka persamaannya akan menjadi $\operatorname{ARIMA}(p, d, q)$.

Bentuk umum dari model $\operatorname{ARIMA}(p, d, q)$ adalah sebagai berikut [6]:

$$
\phi_{p}(B)(1-B)^{d} Z_{t}=\mu+\theta_{q}(B) e_{t}
$$

dengan:

$\phi_{p}(B)$ adalah $\left(1-\phi_{1} B-\phi_{2} B^{2}-\ldots-\phi_{p} B^{p}\right)$ disebut operator autoregressive

$(1-B)^{d}$ disebut differencing dengan ordo $d$ (bilangan asli)

$\theta_{q}(B)$ adalah $\left(1-\theta_{1} B-\theta_{2} B^{2}-\ldots-\phi_{q} B^{q}\right)$ disebut operator moving average.

Model ARIMA sangat efektif digunakan untuk memodelkan data yang tidak stasioner, yang ditunjukkan oleh plot ACF yang turun secara eksponensial atau membentuk gelombang sinus.

\section{PROSES RUNTUN WAKTU JANGKA PANJANG}

Suatu kasus khusus dari proses runtun waktu yaitu proses jangka panjang (long memory). Jika autokovarian suatu proses stasioner dapat dijumlahkan maka proses tersebut memiliki proses jangka pendek, sedangkan jika autokovarian suatu proses stasioner tidak dapat dijumlahkan (nilainya tidak terdefinisi) maka proses tersebut memiliki proses jangka panjang [8].

Identifikasi data yang memiliki proses jangka panjang dapat melihat plot ACF. Jika plot ACF turun secara lambat atau hiperbolik maka data memiliki proses jangka panjang [4]. Identifikasi proses jangka panjang dapat juga ditentukan melalui perhitungan nilai hurst exponent $(H)$ dengan metode rescaled range statistics $(\mathrm{R} / \mathrm{S})$ dengan langkah-langkah sebagai berikut [9]:

1. Menentukan nilai rata-rata $(\bar{Z})$, rata-rata tertimbang $\left(Z_{t}^{a d j}\right)$ dan simpangan baku $\left(s_{t}\right)$ dari data runtun waktu dengan persamaan sebagai berikut:

$$
\begin{gathered}
\bar{Z}=\frac{1}{n} \sum_{t=1}^{n} Z_{t} \\
Z_{t}^{a d j}=Z_{t}-\bar{Z} \\
s_{t}=\sqrt{\frac{1}{t} \sum_{i=1}^{t}\left(Z_{i}-\bar{Z}\right)^{2}}
\end{gathered}
$$

dimana $Z_{t}$ adalah data runtun waktu, $n$ adalah banyaknya data, $t=1,2, \ldots, n$.

2. Menentukan simpangan kumulatif $\left(Z_{t}^{*}\right)$ dari rata-rata tertimbang dan rentang $(R)$ dari simpangan kumulatif.

$$
\begin{gathered}
Z_{t}^{*}=\sum_{i=1}^{t} Z_{i}^{a d j}, \quad \text { dengan } t=1,2, \ldots, n \\
R_{t}=\operatorname{Max}\left(Z_{1}^{*}, Z_{2}^{*}, \ldots, Z_{t}^{*}\right)-\operatorname{Min}\left(Z_{1}^{*}, Z_{2}^{*}, \ldots, Z_{t}^{*}\right), \quad \text { dengan } t=1,2, \ldots, n
\end{gathered}
$$

3. Menentukan nilai Hurst Exponent $(H)$ melalui statistik R/S dari data runtun waku.

$$
\begin{gathered}
\left(R / s_{s}\right)_{t}=c . t^{H}, \quad \text { dengan } t=1,2, \ldots, n \\
\log (R / s)_{t}=\log c+H \log t
\end{gathered}
$$

dimana $c$ adalah suatu konstanta dan $H$ adalah nilai hurst exponent. 
Untuk menaksir nilai $H$ dilakukan dengan mengambil nilai log dari statistik (R/S) dan menaksir nilai $H$ melalui metode ordinary least square (OLS).

$$
H=\frac{\sum_{j=1}^{n}\left(X_{j}-\bar{X}\right)\left(Y_{j}-\bar{Y}\right)}{\sum_{j=1}^{n}\left(X_{j}-\bar{X}\right)^{2}}
$$

dimana: $Y_{j}=\log (R / S)_{t}, X_{j}=\log t$.

Jika:

$H=0,5$ maka menunjukkan data runtun waktu bersifat acak

$0 \leq H<0,5$ maka menunjukkan gejala ketergantungan jangka pendek

$0,5<H \leq 1$ maka menunjukkan gejala ketergantungan jangka panjang

\section{AUTOREGRESSIVE FRACTIONALLY INTEGRATED MOVING AVERAGE (ARFIMA)}

Model ARFIMA merupakan pengembangan dari model ARIMA yang dapat mengatasi kelemahan dari model ARIMA, dimana model ARIMA hanya dapat mengatasi data runtun waktu yang memiliki ketergatungan jangka pendek dengan nilai differencing $(d)$ bernilai bilangan bulat [5].

Model ARFIMA dapat ditulis $\operatorname{ARFIMA}(p, d, q)$ yang dapat memodelkan proses ketergantungan jangka pendek dan jangka panjang pada data runtun waktu. Model ini memiliki tiga parameter sebagaimana model ARIMA yaitu $p, d$ dan $q$, dimana $p$ adalah parameter AR, $q$ adalah parameter MA dan $d$ adalah parameter pembeda berupa bilangan pecahan. Model ARFIMA dapat ditulis sebagai berikut [5]:

$$
\phi(B)(1-B)^{d} Z_{t}=\mu+\theta(B) e_{t}
$$

dimana:

$t=$ indeks dari pengamatan; $d=$ parameter pembeda (bilangan pecahan);

$\phi(B)=1-\phi_{1} B-\phi_{2} B^{2}-\ldots-\phi_{p} B^{p}$ adalah operator $A R(p)$;

$\theta(B)=1-\theta_{1} B-\theta_{2} B^{2}-\ldots-\theta_{q} B^{q}$ adalah operator $M A(q)$;

$(1-B)^{d}$ disebut differencing $(d),(1-B)^{d}$ pada model ARFIMA diekspansikan sebagai Deret Binomial hal ini dikarenakan nilai dari parameter pembeda berbentuk pecahan.

Persamaan $(1-B)^{d}$ pada model $\operatorname{ARFIMA}(p, d, q)$ dapat ditulis sebagai berikut [5]:

$$
(1-B)^{d}=\sum_{k=0}^{\infty}\left(\begin{array}{l}
d \\
k
\end{array}\right)(-B)^{k}
$$

dengan $\left(\begin{array}{l}d \\ k\end{array}\right)=\frac{d !}{k !(d-k) !}=\frac{\Gamma(d+1)}{\Gamma(k+1) \Gamma(d-k+1)}$ dan $\Gamma(x)$ merupakan fungsi gamma sehingga jika Persamaan (13) dijabarkan maka diperoleh [5]:

$$
(1-B)^{d}=1-d B-\frac{1}{2}(1-d) d B^{2}-\frac{1}{6}(1-d)(2-d) d B^{3}+\ldots
$$

\section{IDENTIFIKASI DATA}

Data yang digunakan dalam penelitian ini adalah data harga crude palm oil (CPO). Data yang digunakan berupa data mingguan dari periode 1 Januari 2012 sampai 10 Maret 2019. Data in-sample yang digunakan adalah data pada periode 1 Januari 2012 sampai 30 Desember 2018, sedangkan data out-sample yang digunakan adalah data pada periode 6 Januari 2019 sampai 10 Maret 2019. Berdasarkan Gambar 1 plot pada data harga CPO terlihat belum stasioner karena titik-titik tersebut tidak berfluktuasi 
disekitar rata-rata yang konstan. Untuk melihat apakah data stasioner dalam variansi dapat menggunakan transformasi Box-Cox.

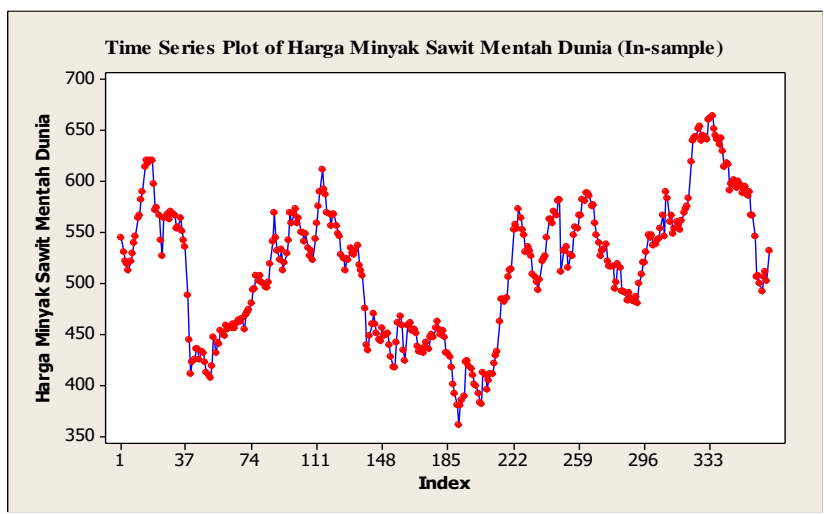

Gambar 1 Plot Runtun Waktu Harga CPO

Hasil dari transformasi Box-Cox diperoleh bahwa nilai dari rounded value sebesar 1, hal ini menunjukkan data sudah stasioner dalam variansi. Pada Gambar 1 dapat diketahui bahwa data belum stasioner dalam rata-rata karena pola data tidak berfluktuasi di sekitar rata-rata. Namun pada langkah ini data tidak distasionerkan dalam rata-rata karena dalam pemodelan ARFIMA hanya mensyaratkan data stasioner dalam variansi.

Langkah selanjutnya adalah membuat plot ACF dan plot PACF. Plot ACF disajikan pada Gambar 2 sedangkan Plot PACF disajikan pada Gambar 3:

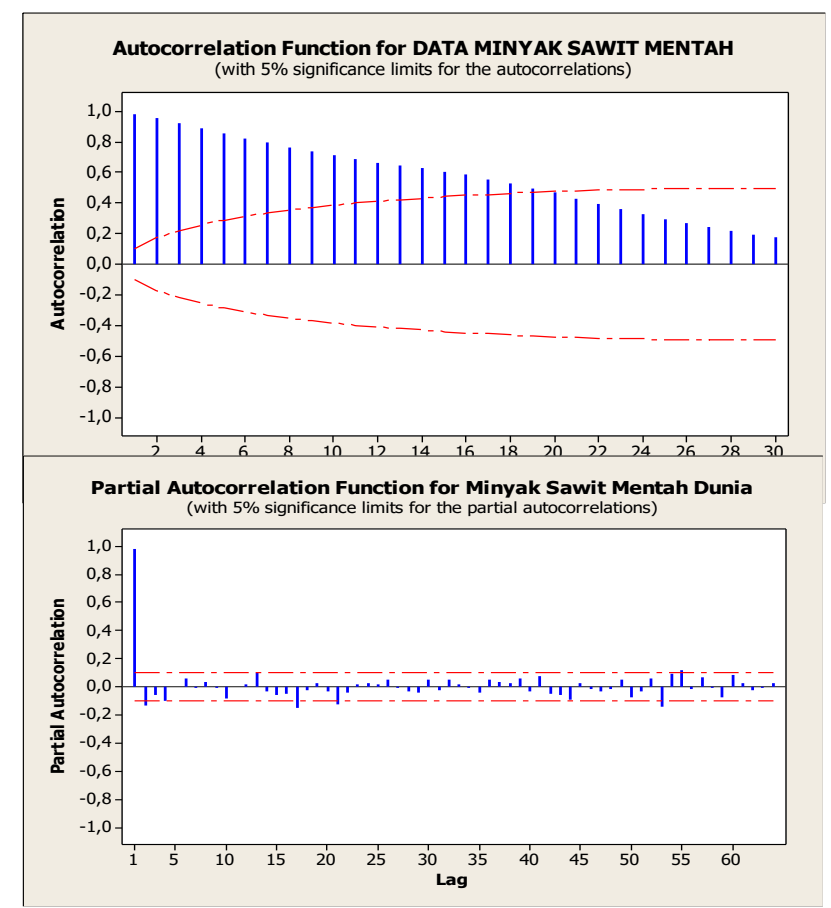

Gambar 3 Plot Partial Autocorrelation Function (PACF)

Identifikasi pola long memory dapat dilihat dari plot ACF. Berdasarkan Gambar 2 dapat dilihat bahwa plot ACF turun secara lambat hal ini mengindikasikan bahwa data mengandung efek long memory. Identifikasi pola long memory dapat juga ditentukan melalui perhitungan nilai hurst exponent $(H)$. Pada penelitian ini perhitungan nilai $H$ menggunakan metode rescaled range statistics. Nilai $H$ yang diperoleh sebesar 0,867 sehingga sifat long memory pada data harga CPO telah terbukti. Identifikasi ini mengindikasikan bahwa nilai dari koefisien pembeda bernilai pecahan, sehingga model yang cocok untuk meramalkan data harga CPO adalah model ARFIMA. 


\section{IDENTIFKASI MODEL ARFIMA}

Setelah diketahui bahwa data mengandung sifat long memory, langkah selanjutnya adalah menentukan model yang mungkin digunakan dalam pemodelan ARFIMA. Berdasarkan plot ACF dan plot PACF pada Gambar 2 dan Gambar 3 didapat beberapa kemungkinan model. Pada Gambar 2 dapat dilihat bahwa autokorelasinya turun secara lambat. Pada Gambar 3 terlihat bahwa plot PACF tampak terpotong pada suatu lag. Ini menunjukkan kecenderungan data memiliki model autoregressive (AR). Berdasarkan Gambar 3 terlihat bahwa plot PACF terdapat lag yang keluar dari garis, yaitu pada lag 1 dan 2. Adapun kemungkinan model untuk proses ketergantungan jangka panjang adalah:
1. ARFIMA $(1 ; d ; 0)$
6. ARFIMA $(1 ; d ; 2)$
2. $\operatorname{ARFIMA~}(1 ; d ; 1)$
7. ARFIMA $(2 ; d ; 0)$
3. ARFIMA ([2]; $d ; 0)$
8. ARFIMA $(2 ; d ; 1)$
4. ARFIMA $([2] ; d ; 1)$
9. $\operatorname{ARFIMA~}(1 ; d ;[2])$
5. ARFIMA ([2]; $d ;[2])$

Dari beberapa kemungkinan model yang didapat, dapat dilihat jika terdapat model yang hanya dibedakan oleh tanda kurung yang menunjukkan adanya perbedaan antara kedua model. Misalnya perbedaan dari model ARFIMA ([2]; $d ; 1)$ dan model ARFIMA $(2 ; d ; 1)$ adalah untuk model ARFIMA ([2]; $d ; 1$ ) menunjukkan bahwa parameter model yang diestimasi adalah $d$, model AR(2), model MA(1), sedangkan untuk model ARFIMA $(2 ; d ; 1)$ menunjukkan bahwa parameter model yang diestimasi adalah $d$, model $\mathrm{AR}(1), \operatorname{AR}(2)$ dan $\mathrm{MA}(1)$.

\section{ESTIMASI PARAMETER MODEL ARFIMA}

Estimasi parameter model ARFIMA menggunakan metode exact maximum likelihood (EML). Estimasi parameter ARFIMA dengan metode EML dilakukan secara serentak untuk semua parameter dan diperbaiki secara iteratif. Hal ini menyebabkan nilai estimasi parameter $d$ dapat berbeda-beda [4]. Hasil estimasi parameter model yang signifikan dapat dilihat pada Tabel 1.

Tabel 1 Hasil Estimasi Parameter Model

\begin{tabular}{ccccc}
\hline Model & Parameter & Koefisien & $\boldsymbol{P}$-Value & AIC \\
\hline ARFIMA & $d$ & 0,17 & 0,006 & \multirow{2}{*}{7,999} \\
\cline { 2 - 4 }$(1 ; d ; 0)$ & $\mathrm{AR}(1)$ & 0,942 & 0,000 & \\
\cline { 2 - 4 } & Konstanta & 521,7 & 0,000 & \\
\hline ARFIMA $([2] ; d ; 1)$ & $d$ & 0,169 & 0,007 & \multirow{2}{*}{8,005} \\
& $\mathrm{AR}(2)$ & 0,889 & 0,000 & \\
\cline { 2 - 4 } & $\mathrm{MA}(1)$ & 0,944 & 0,000 & \\
\cline { 2 - 4 } & Konstanta & 521,68 & 0,000 &
\end{tabular}

Suatu model ARFIMA dikatakan signifikan apabila nilai $p$-value $<0,05$. Dapat dilihat pada Tabel 1 bahwa kedua model ARFIMA signifikan.

\section{UJI DIAGNOSTIK}

Uji diagnostik yang dilakukan adalah uji asumsi nilai sisa white noise dengan menggunakan uji Ljung-Box. Model dikatakan white noise apabila plot ACF dan PACF dari nilai sisa model ARFIMA tidak melebihi garis dan semua nilai $p$-value $>0,05$. Berdasarkan hasil uji Ljung-Box model ARFIMA $(1 ; 0,17 ; 0)$ dan ARFIMA ([2]; 0,169;1) bersifat white noise. Hal ini menunjukkan bahwa model ARFIMA $(1 ; 0,17 ; 0)$ dan ARFIMA $([2] ; 0,169 ; 1)$ layak untuk digunakan dalam peramalan. 


\section{PEMILIHAN MODEL TERBAIK}

Pemilihan model terbaik untuk model ARFIMA dilakukan dengan membandingkan nilai AIC. Berdasarkan Tabel 1 dapat dilihat bahwa model yang memiliki nilai AIC terkecil adalah model ARFIMA $(1 ; d ; 0)$ dengan nilai AIC sebesar 7,999 sehingga model yang tepat untuk digunakan dalam penelitian ini adalah model ARFIMA $(1 ; d ; 0)$ dengan nilai $d=0,17$.

Secara matematis, persamaan model ARFIMA $(1 ; 0,17 ; 0)$ dapat ditulis sebagai berikut:

$$
Z_{t}=521,7+1,112 Z_{t-1}-0,09 Z_{t-2}-0,0229 Z_{t-3}-\ldots-0,0001413 Z_{t-367}+e_{t}
$$

Dari model ARFIMA yang didapat, dapat dikatakan bahwa harga CPO saat ini dipengaruhi oleh harga CPO pada periode-periode sebelumnya dan juga nilai error pada saat ini.

\section{PERAMALAN}

Setelah mendapatkan model ARFIMA terbaik, langkah selanjutnya adalah melakukan peramalan pada data harga CPO. Hasil peramalan harga CPO disajikan pada Tabel 2.

Tabel 2 Hasil Peramalan Harga CPO dengan Model ARFIMA $(1 ; 0,17 ; 0)$

\begin{tabular}{cccc}
\hline Minggu ke- & Tanggal & $\begin{array}{c}\text { Data Aktual } \\
\text { (dalam INR) }\end{array}$ & $\begin{array}{c}\text { Hasil Peramalan } \\
\text { (dalam INR) }\end{array}$ \\
\hline 1 & 6 Januari 2019 & 545,7 & 536,1 \\
2 & 13 Januari 2019 & 551,6 & 548,2 \\
3 & 20 Januari 2019 & 560,0 & 553,0 \\
4 & 27 Januari 2019 & 567,1 & 561,3 \\
5 & 3 Februari 2019 & 570,5 & 568,0 \\
6 & 10 Februari 2019 & 559,7 & 570,8 \\
7 & 17 Februari 2019 & 560,7 & 558,1 \\
8 & 24 Februari 2019 & 556,8 & 559,9 \\
9 & 3 Maret 2019 & 538,0 & 555,6 \\
10 & 10 Maret 2019 & 522,6 & 534,9 \\
\hline
\end{tabular}

Dapat dilihat pada Tabel 2 bahwa hasil peramalan harga CPO pada minggu pertama yaitu pada tanggal 6 Januari 2019 sebesar 536,123 (mata uang dalam INR) atau sebesar Rp108.516,65/10kg, sedangkan harga CPO asli pada tanggal 6 Januari 2019 adalah 545,7 (mata uang dalam INR) atau sebesar Rp110.455,137/10kg. Proses peramalan harga CPO periode 6 Januari 2019 sampai dengan 10 Maret 2019 dengan menggunakan metode ARFIMA $(1 ; 0,17 ; 0)$ dinilai cukup akurat karena menghasilkan nilai MAPE sebesar $1,37 \%$. Model ini masuk dalam kriteria kemampuan peramalan sangat baik karena nilai MAPE yang diperoleh kurang dari $10 \%$.

\section{KESIMPULAN}

Berdasarkan hasil dan pembahasan diperoleh model terbaik untuk meramalkan harga CPO yaitu model ARFIMA $(1 ; d ; 0)$, dengan nilai $d=0,17$. Bentuk persamaan dari model ARFIMA $(1 ; 0,17 ; 0)$ adalah $Z_{t}=521,7+1,112 Z_{t-1}-0,09 Z_{t-2}-0,0229 Z_{t-3}-\ldots-0,0001413 Z_{t-367}+e_{t}$. Dari model ARFIMA $(1 ; 0,17 ; 0)$ diperoleh hasil peramalan harga CPO untuk 10 minggu kedepan dengan nilai AIC sebesar 7,999 dan nilai MAPE sebesar 1,37\%.

\section{DAFTAR PUSTAKA}

[1]. Kementrian Pertanian Republik Indonesia. Rencana Strategis Kementrian Pertanian Tahun 2015-2019;2015.

[2]. Badan Pusat Statistik. Statistik Kelapa Sawit Indonesia 2017. Badan Pusat Statistik;2018. 
[3]. Makridakis, S., Wheelwright, S. C., dan McGee, V. E. Metode dan Aplikasi Peramalan. Jakarta: Bina Rupa Aksara;1999.

[4]. Ningrum, L. K. dan Sulandari, W. Penerapan Model Arfima (Autoregressive Fractionally Integrated Moving Average) Dalam Peramalan Suku Bunga Sertifikat Bank Indonesia (SBI). Prosiding Seminar Nasional Matematika dan Pendidikan Matematika Jurusan Pendidikan Matematika FMIPA UNY;2009.

[5]. Hosking, J. R. M. Fractional Differencing. Biometrika. 1981;1(68):165-176.

[6]. Wei, W. W. S. Time Series Analysis: Univariate and Multivariate Methods Second Edition. New York: Addison Wesley;2006.

[7]. Cryer J.D dan Chan K.S. Time Series Analysis. With Applications to R. January. New York: Springer Science Business Media, LLC;2008.

[8]. Palma, W. Long Memory Time Series Theory and Methods. Canada: Wiley;2007.

[9]. Natanael, D. K.; Safitri, D dan Suparti. Prediksi Harga Minyak Dunia Dengan Metode Autoregressive Fractionally Integrated Moving Average (ARFIMA). Jurnal Gaussian. 2018;1(6):65-72.

IKA AYU KRISMAWANTI

SHANTIKA MARTHA

NAOMI NESSYANA DEBATARAJA
: Jurusan Matematika FMIPA UNTAN, Pontianak ikaayukrismawanti@student.untan.ac.id

: Jurusan Matematika FMIPA UNTAN, Pontianak shantika.martha@math.untan.ac.id

Jurusan Matematika FMIPA UNTAN, Pontianak naominessyana@math.untan.ac.id 